\title{
Hayek's Appreciative Theory and Social Justice
}

\begin{abstract}
Nick Cowen ${ }^{1}$
Peter J. Boettke's F.A. Hayek: Economics, Political Economy and Social Philosophy (2018) is an impressive synopsis and powerful defense of Hayek's scholarship framed as a project of epistemic institutionalism (cf. Boettke, 2002; Boettke and Candela, 2017). One claim that I find particularly enlightening is that Hayek offers an appreciative theory of market institutions, in opposition to the formal descriptions and proofs of mainstream economics (Boettke, 2018: 107108; Boettke and Coyne, 2009: 12; Nelson and Winter, 2004: 47). This interpretation is important, but not because it's the only way of reading Hayek. Rather, the lack of an appreciative perspective explains the various ways that Hayek's insights have been misconstrued. As Boettke (2018: 97) documents, neoclassical economists have at times claimed to build on Hayekian insights or inquiry. But in the process of formalization they have lost the essence of Hayek's discovery: that a great deal of relevant information for economic decision-making can only be discovered through processes of trial and error (Boettke, 1997; Boettke and O'Donnell, 2013).

Boettke focuses on Hayek's engagement with and reception among economists. However, examples of these difficulties in translation also crop up among political theorists who have engaged with Hayek. Scholars of politics on the left have generally conceived Hayek as an intelligent 'enemy' who can help clarify the feasibility of some of their moral commitments but who cannot participate in the same project of establishing a truly just society (Griffiths, 2014). Nevertheless, there have been several attempts, increasingly successful, to integrate Hayekian insights into normative political philosophy (Schmidtz and Brennan, 2012; Tomasi, 2012a, 2012b).
\end{abstract}

My aim, therefore, in this essay is to contribute to Boettke's project by bridging the gap between the Hayekian critique of social justice and its reception among normatively committed theorists and philosophers. I begin by summarizing some inter-related cases proposed by political theorists for rejecting Hayek's critique of social justice. I add to Boettke's resources some context around Hayek's epistemology that establishes quite how deep the problem of

\footnotetext{
${ }^{1}$ Lecturer, School of Social and Political Sciences, University of Lincoln.
} 
coordination goes. I explain the necessary role that appreciative theory plays in our way of understanding the relationship between social morality and society. I then explain how appreciative theory goes some way to answering Hayek's critics. This highlights the possible overlap between Rawlsian and Hayekian approaches to public policy. Finally, I outline how a positive research program might combine Hayekian insights with the pursuit of social justice, or at the very least the progressive amelioration of the conditions of the relatively disadvantaged.

\section{Critics of Hayek on social justice}

Students of political philosophy might not often encounter Hayek. Nozick (2013) has tended to be treated as the adequate representative of "right-wing" political philosophers (Schmidtz and Brennan, 2012). However, Hayek does make an important appearance in Swift's Political Philosophy: a beginner's guide for students and politicians (2010: 20-23), as the paradigmatic skeptic of social justice who inspired British Prime Minister Margaret Thatcher's free-market agenda of the 1980s. Proponents disagree on the content of social justice. However, they agree that political institutions should be evaluated on the way they distribute essential resources, status and opportunities to individuals and groups in a community. This could be a narrow demand that everyone has enough resources to live reasonable lives; or a broader claim for distributive equality; or a presumed baseline for equality that permits some inequalities only under specific conditions.

Hayek (1976), by contrast, claims that social justice is meaningless, atavistic (the product of an old intuitive, indeed religious, conception of morality), unfeasible, and incompatible with a market economy. Swift concentrates his critique on Hayek's argument for treating social justice as a category mistake, one that imputes responsibility to an amorphous 'society' where no individual agent can be held responsible. Swift responds that it is trivial that we can be collectively responsible for the outcomes produced or permitted by political decisions. Shared responsibility does not mean no responsibility.

Swift's summary reflects a common starting point of several criticisms of Hayek in political thought. Gamble (2013) suggests that Hayek's insistence that only intentional acts are capable of injustice ends up impoverishing his broader theory. Thus, with only a negative notion of liberty and a narrow definition of coercion (only possible through deliberate acts), Gamble suggests that people's choices and opportunities within a Hayekian framework can end up systematically 
restricted just as long as the process producing it is unintended. Johnston (1997) argues that Hayek fails to recognize that the ends of social justice can be pursued through indirect means rather than brute interventions and that he underestimates the contribution of market institutions themselves to generate oppressive social environments.

Tebble (2009) points out that the claims of meaninglessness and atavism may make some sense against those imputing justice to market outcomes alone but that correcting them after the fact to bring the results into line with social justice can still be meaningful. Moreover, Tebble claims that Hayek falls into contradiction by permitting a minimal welfare state but on moral grounds that he dismisses elsewhere (cf. Plant, 2010: 218). To avoid contradicting himself, Hayek would have to pursue a much more radical argument for laissez-faire involving rigorously competitive and decentralized solutions to welfare.

Lukes (1997) similarly turns aspects of Hayek's critique on itself. He suggests that just because a moral norm, like social justice, has non-rational, even religious, origins does not render it meaningless. Indeed, it could be its very ancient origins and enduring attraction among people's sense of morality that explains why you need a conception of social justice for minimal political legitimacy to obtain. Moreover, he argues that insisting on abstract, general rules based on formal equality in the place of social justice is hardly a sure escape from de facto coercion and restraints on basic liberties (Lukes, 1997: 77). Williams (1997) argues that Hayek never successfully separates his account of the rule of law from his undefended but controversial theory of economic rights.

Lister $(2013$, 2017) draws attention to Hayek's and Rawls's (1971) common inspiration in Knight (1921) about the ineliminable uncertainty of economic life. Both, as a result, avoided making distributive claims with regards to desert. Lister argues that once a supposed conceptual divergence between Rawls and Hayek is collapsed, contemporary Hayekians are left defending their position based on controversial empirical claims about the contribution of competitive markets to improving the condition of the least well-off.

The overall appraisal of Hayek is that he voices reasonable concerns about some peripheral arguments of social justice theorists. But his fundamental and aggressive rejection of social justice is unwarranted due to his own position on what governments may do and his explicit support for a Rawlsian' approach. This characterization is plausible when reading Hayek's rather 
polemical attacks on social justice in isolation. Indeed, as Boettke (2018: 2) acknowledges, there are moments where Hayek's stridence undermines his aims, and this is arguably one of those moments. Nevertheless, there is a Hayekian response once his position is understood within his broader project of epistemic institutionalism. This account can explain why some minimal, indeed arguably quite substantial, provisions of a welfare state can be supported wholeheartedly from within Hayek's approach while still ruling out more systematic forms of intervention in the economic realm. It can also help us understand more positively how exactly to pursue successful public policy reform.

\section{Moral theorizing, spontaneous orders and appreciative theory}

A key part of the challenge of bridging the gap between Hayek's epistemic institutionalism and theories of social justice comes from a different method to normative theorizing. Many scholarly proponents of social justice, especially those working within or influenced by analytic philosophy, take the task of political philosophy to be a subset of what they describe as applied ethics. Generally, the task of applied ethics is to refine moral judgements and intuitions in order to establish and defend coherent moral principles based on rational justification (Knight, 2017; McDermott, 2008).

For some theorists, famously Cohen (2003), guiding moral principles can be established without much (if any) reference to empirical facts. Other theorists are more motivated to include sociological facts. However, they tend to arise as feasibility constraints on moral theories (Swift and White, 2008). Normative theorists treat the intuitions, judgements and principles that we find deployed in ordinary language as the building blocks of more systematic moral philosophy. It is presumed that ordinary ethical discussion, analytically refined through philosophical deliberation and reflection, will eventually point to meaningful, coherent principles. It is the role of a different kind of theorist to inquire about the ontological status of moral principles and judgements rather than their content. Out of necessity, moral philosophy precedes on the assumption that they have some underlying reality (McDermott, 2008: 16).

For Hayek, the point of departure is different. His theoretical endeavor is chiefly to explain a puzzle: the remarkable capacity for humanity to engage in cooperation at the scale of a political community despite widespread, manifest ignorance. Hayek's answer is that liberal institutions of private property and voluntary contract under the rule of law permits economic coordination. 
Liberal institutions achieve this by generating the social circumstances whereby people can make use of knowledge that is not their own (Hayek, 1937; Kiesling, 2015). These institutions permit a competitive market and price system to emerge that allows local knowledge of scarcities and demands for goods, services and, critically, intermediate factors of production (capital) to be conveyed throughout an entire society (Lavoie, 1986). Without such a regime in place, individuals engaging in economic activity have no way of knowing whether their efforts are making a genuinely productive contribution to a community or are wasting valuable resources. With such institutions in place, individuals and firms receive continuous feedback, through the realization of profit and loss, allowing them to continuously adjust their activity to changing availabilities of resources and consumer preferences.

The result is an example of what Hayek identifies as a spontaneous order (D'Amico, 2015; Hayek, 1945; Menger, 1985: 146). Market institutions permit individuals to carry out their own plans within a framework of established legal rules with the aggregate result (if not necessarily the intention of those working within the framework) of producing socially desirable, though not assuredly optimal, outcomes. As Boettke (2018: 189) describes:

The economic process is neither an evolutionary natural selection process that assures the survival of the "best" or "fittest," nor is it a chaotic and random walk. The discovery of the competitive market is a learning process- a process of trial and error and experimentation in which the key component is the ability to reveal error and motivate the discovery of new knowledge about economic opportunities... The superiority of the market process lies not in its ability to produce optimal results, but rather in its ability to mobilize and effectively use knowledge that is dispersed throughout the economic system.

Although never perfect, the outcomes of this market process, that Hayek also calls catallaxy, are more complex and make better use of resources than any conceivable centralized arrangement developed through rational planning.

Some of this account is conceivable (even plausible) to theorists of social justice when applied narrowly to economic activity itself. Like the neoclassical economists who sought to formalize Hayek's explanatory framework, they can recognize the informational challenges that market institutions appear able to overcome at least in the supply of private goods (Carens, 1981; Miller, 1990). They can propose a role for markets that a sufficiently informed citizenry would endorse, as Rawls (1999: 240) did when lauding the 'allocative' function of markets (while contesting their distributive role). The implication is that the institutions of the market economy can be 
established, and indeed fine-tuned, in order to achieve common ends but must be carefully constrained so as not to generate too much instability.

From a Hayekian standpoint, however, recognition of the beneficial impact of activity taking place within markets is only the beginning of a much broader account of social order that includes many other institutions, including law, language, social norms and morality itself (Albrecht, 2017: 357; cf. Ostrom, 1993). From this more radical social evolutionary standpoint, the description of spontaneous order does not apply only to the results of activity within a framework of rules, but to the emergence of the rules themselves. Norms and institutions are principally developed as a result of human action but not design or individual intention.

It is worth emphasizing how fundamental the epistemic challenge is for Hayek. He argues that our basic sensory faculties are constitutionally incapable of accessing putative real entities in an objective physical universe (Caldwell, 2004; Hayek, 1952). Instead, we make sense of irreducibly complex 'concrete orders' that constitute our raw holistic sensory experience through the generating, testing and refining of abstract orders (Hayek, 1981). These categories are simplified models that help us pick out relevant and salient features of phenomenal reality. Because they cannot ever represent complete knowledge of reality, they are constantly open to error-correction and adaptation in the face of novel phenomena. An interesting feature of this account is that human minds themselves bear a resemblance to spontaneous orders. Cognition of our surroundings emerges not through systematic reflection on individuated sense-data but through adapting our categories to observable patterns of phenomena through constant trial and error. What eventually takes the form of reason and logic is an emergent property resulting from the mind interacting with the world and incrementally developing more refined abstract categories and understanding of the temporal and structural relationships between phenomena.

On this epistemically austere account, there is no reason to expect a direct correspondence between the concepts we use, especially ordinary language, and an objective reality. Instead, our conceptual frameworks are inter-subjective: patterns, categories and rules constituted through social interaction and the resulting practices (Boettke and Storr, 2002). Our theoretical frameworks for morality are no exception to this general description. From this perspective, exploring morality without inquiring as to its relations with other features of social reality is unlikely to be fruitful. The concepts that make up our moral frameworks are forged through 
continuous interaction and adjustment between mind and culture (Boettke, 2018: 190). Unlike social interaction and exchange within an established market framework where people have some assurance of individual security, there can be no expectation that the results of human interaction in general will be broadly beneficial (cf. Leeson and Boettke, 2009). There is no teleology in Hayek's account of institutional emergence and a Hobbesian state of nature is historically more common than a liberal social order. Nevertheless, the role of social institutions, and explanation for their emergence and stability in the absence of a single determining agent must be established before their performance for facilitating wellbeing can be evaluated.

Social morality and law are part of our abstract ordering that, once it emerges, allows us to impose some predictability on our conduct and the expectations we have of others. This is what makes the liberal institutions of private property under the rule of law different from other kinds of social rules. These institutions take the complex, variegated social and natural phenomena we encounter and categorizes them in such a way that we can make general predictions about what we may or may not do in social situations. It makes the social world more modular, allowing us to understand what sort of conduct counts as legitimate in our protected sphere of activity and areas of competence (Cowen, Forthcoming). Once baseline expectations are settled in an environment where experimentation is permitted and the results of successful productive experiments protected, individuals can occupy themselves in continuously improving their subjective conditions (and that of others) while maintaining their autonomy.

How exactly can this emergent account of a cooperative social order gain credibility? This is the peculiar role that appreciative theory plays. One of Hayek's recurring themes is to make use of reason to identify the limits of reason. From Hayek's standpoint, we have limited, defeasible knowledge of our immediate environment that can become more refined through trial and error learning. We have even more constrained access to other relevant information about our wider social environment and must rely almost completely on indirect knowledge. We can never be well-situated to understand society with precision. We cannot rely on applying proofs of systematic relationships between well-defined social conditions and factors, because the way we conceptualize those factors is necessarily simplified and unable to contain all the complex social phenomena we are trying to explain. 
What we have instead are informal models (or analytic narratives), often ones with various kinds of empirical evidence and thick description to motivate them. The conclusions of appreciative theory emerge out of the careful, open-ended observation of patterns of relations seen in comparisons between contemporary and historical societies that show in which conditions theories are likely to be applicable and when they are not (Boettke et al., 2013). One inspiration for this kind of method is the conjectural history that characterizes the Scottish Enlightenment enterprise (Höpfl, 1978). This certainly does not imply ignoring systematic empirical data when it is available or formal models, especially as 'foils' to establish the limit conditions of particular claims (cf. Albrecht and Kogelmann, 2018). It merely proposes that any theorizing about reality begins with the contestable division of subjective phenomena into categories that are subject to revision, especially about the domain in which the theory applies.

\section{Implications of appreciative theory for social justice}

Appreciative theory is not a Panglossian enterprise. It is a realistic perspective that recognizes the pervasive limits of our knowledge as individuals and political actors, our necessary reliance on social institutions to comprehend reality on a fundamental level, and, as a result, the marvel of the complex extended order that liberal institutions facilitate but no single person can fully comprehend. I now briefly suggest how this perspective answer some concerns with Hayek's account.

\section{Individual contributions to aggregate outcomes}

A valuable point that proponents of social justice make is that just because a state of affairs has arisen by unguided processes does not mean it is normatively justified. That would be to commit something akin to the naturalistic fallacy- a trap into which classical liberal theories can occasionally fall. Nevertheless, there is a kind anti-naturalistic fallacy that shadows much normative theory. It presumes that any feature of society that lacks clear rational justification is likely to be normatively unjust (Lister, 2013: 414). This assumption is explicit in conflict theories of society which precede on the basis that social struggles underlie even comparatively peaceful social orders and that all social outcomes are the result of a set of dominant interests winning a competition for power. However, the assumption is also present in any political theory that presumes all social outcomes must ultimately be subject to rational justification. The notion that government action may not align with benevolent intentions is easily imagined by any social 
critic. The more radically skeptical notion that government, ultimately a set of individuals acting within institutional rules, has limited capacity to act and does so in the midst of pervasive ignorance is much harder to grasp and yet fundamental to Hayek's liberal political economy (Furton and Martin, 2018).

What appreciative theory offers is a kind of symmetry between the intended and unintended consequences of individual action. From the social justice theorists' standpoints, we are responsible for our personal conduct to a considerable degree. However, we also share in the responsibilities for the injustices or disadvantages produced by those social institutions, in which we participate. From the appreciative standpoint, if we bear some responsibility for collectively produced poor outcomes, then we must also share in the collective beneficence of outcomes produced through the various spontaneous processes of cooperation in which we participate.

It is not chiefly our personal participation in formal political processes that is responsible for the good that we bring to others but our actions as producers for the market, family members and contributors to civil society. For example, it is not a government or distinct group that is responsible for the annual production of goods and services of a community, and their normally expected annual increase in developed economies, but everyone who has made any kind of productive contribution inside or outside of markets themselves (Boettke, 2018: 268; McCloskey, 2007). Within a framework of a liberal order, even where people's averred intentions do not reach the summit of social justice, nevertheless traditional moral conduct, including a commitment to hard work, respect, civility and deferred gratification produce broad benefits for people throughout society.

\section{Rule of law}

Within the framework of applied ethics, technical legal principles like the formal rule of law and secure property rights do not seem to have a direct connection with the fundamental interests or rights of individuals. They appear to play an instrumental or political role rather than a moral one. The insistence on the rule of law above other substantive moral goals can appear, at best, to be a necessary feasibility constraint to prevent poor governance, but often more likely to represent an unhealthy obsession with formality or process over consequences. 
The rule of law, especially when used in defense of individual property rights, might appear to be based on a moral principle that one should avoid an individual's reasonable expectations being disappointed because presumably that interferes with individual autonomy (the underlying moral value at stake) (Gamble, 2013: 346; Plant, 2010: 79). Of course, it is not only governments that disappoint individual expectations. Expectations are disappointed by natural accidents, as well as through ordinary competitive market behavior and decisions taken by individuals in civil society. A Hayekian emphasis on the rule of law to restrict state action alone seems, on the one hand, excessively stern and, only the other hand remarkably partial since it fails to address other forms of uncertainty and disappointment that humans encounter.

However, within an appreciative framework, the rule of law is not purely formal but is justified on a substantive intention to carve out spheres of activity where people are free from the arbitrary will of others. This can be illustrated with a parallel that has been discussed on several occasions in this debate (Schmidtz, 2010). Systems of traffic rules and management include various general, formal rules that apply in all circumstances and to all participants. Others vary depending on the kind of vehicle one is driving or if one is a pedestrian. In addition to rules, traffic systems involve building physical infrastructure that makes it safer for travelers and as clear as possible how the rules will apply in each case through both road design and standardized signs. The system does involve some substantive changes to the environment to make it easier to follow the rules, though limited to the road network. Such systems are established with the common, public (but relatively thin) goal of allowing people to travel safely throughout a community.

Similarly, Hayek's commitment to the rule of law involves both formal generality and substantive content, with the common goal of generating circumstances in which people are capable of both experimenting and planning to discover how to make a positive contribution to social cooperation. When denied this structure of liberty, individuals are rendered dependent on the arbitrary will of those with political authority to have their basic needs fulfilled (cf. Trantidis and Cowen, 2019). From this standpoint, the rule of law, especially as applied to economic life, has primarily social rather than individual value because it allows individuals to avoid imposing burdens on others, while also making a productive contribution to their betterment. Thinking back to our traffic management illustration, generally applicable rules are vastly superior for 
preventing traffic accidents than arbitrary commands because only general rules empower individual travelers to act appropriately based on their situated knowledge.

\section{Rawls and Hayek}

Hayek acknowledges that justice is an important criterion for legitimizing formal political institutions. As a result, his criticisms of social justice, in general, avowedly do not apply to the Rawlsian framework because it distinguishes between a basic structure where justice applies and the rest of civil society:

...there unquestionably also exists a genuine problem of justice in connection with the deliberate design of political institutions, the problem to which Professor John Rawls has recently devoted an important book. The fact which I regret and regard as confusing is merely that in this connection he employs the term "social justice". (Hayek, 1976: 100)

Hayek quotes Rawls' explanation of justice applying not to 'specific systems or distributions of desired things' (1976: 100) but as applying to constraints on a basic structure. Nevertheless, Hayek and Rawls disagree on the contours of that basic structure. From Hayek's appreciative standpoint, this is because it is impossible for institutions to determine in detail the outcomes of economic exchange and political activity. The best institutions governing a whole political community can do is facilitate generally beneficial patterns of cooperation. Hence, evaluating relative distributive shares between groups, which Rawls makes a key part of the content of justice, is too epistemically ambitious.

Both Rawlsian and Hayekian approaches also make use of comparative analysis (Cowen, 2017). In Rawls' (1999) case, his procedural approach to identifying principles of justice involves representative agents reasoning back and forth between various alternative conceptions to see which are most plausibly compatible with our intuitions and particular concrete problems (Kukathas and Pettit, 1990: 8). The principles of justice are not deduced from logical axioms but argued to be the ones that would be selected from a menu of plausible options.

So there is an overlap between Rawlsian and Hayekian approaches. Yet Rawls ultimately decides that the comparison of institutional arrangements points decisively against capitalism and in favor of either socialism or a property-owning democracy (an idealized regime type not yet seen in reality). What really makes the difference is the approach to economic inquiry. Pace Knight's early influence (Lister, 2017), Rawls endorses a static formal approach to economic modelling that 
characterizes the neoclassical approaches of Meade (2012) and Samuelson (1947). This account explains the success of market economies in terms of a general equilibrium under conditions of perfect competition. However, as its proponents often assert, this perfect competition model is rendered irrelevant when faced with externalities, public goods and other collective action problems. The model purporting to explain the efficiency properties of markets ends up serving to highlight the scant cases in which we would expect markets to work in practice.

Hayek begins instead with the appreciative observation that many needs are met through individuals, guided by market prices, making incremental improvements to their productive activities. This observation cannot be adequately explained by a model of perfect competition which, of course, no one believes obtains realistically given human actors with limited knowledge. It is this realistic epistemic challenge that indicates the comparative performance of privateproperty markets against state-owned or state-directed alternatives. Hence, Rawls' reliance on formal models that lack salient features to explain realistic observations of economic activity explains his practical divergence from Hayek.

Meade (2012) also makes strong predictions about the automatic accumulation and growth of capital, a claim that Piketty (2014) has subsequently re-asserted. This is what justifies Rawls' insistence either on state-control of significant means of production or constant measures to disperse such control to citizens who cannot be expected to acquire it themselves under market conditions. However, these predictions are based on strong assumptions about the growth of capital. These follow the neoclassical framework but do not explain economic history particularly well (Acemoglu and Robinson, 2015). From a Hayekian standpoint, what we call capital is a loose category of goods that entrepreneurs believe to be valuable as part of intermediate stages of production (cf. Kirzner, 2012; Delmotte and Cowen, 2019). We would not expect such variegated phenomena to exhibit a structural tendency to accumulate independently of human action and institutional context (Cowen, 2018). When observing changes in wealth holdings, we are looking for some other less abstract explanation than capital accumulation, something that is compatible with the compositive results of individual action (Boettke et al., 2005).

\section{Principles for progress}


At this point, a conservative theorist might stop, concluding that whatever class or income group we find ourselves in, we are enormously fortunate to live in a developed commercial society compared to any alternative regime, past or present; and that the concerns of contemporary social justice advocacy are trivial. That would be appreciation as apologetics. Indeed, Hayek offers some resources for a conservative theorist making that sort of argument. But Hayek's social philosophy does not need to stop there and should not, because there are many persistent patterns of injustice that manifest, even under liberal regimes (Novak, 2018). We can recognize them as requiring urgent reform. But those reforms will only be successful if they follow an appropriate analysis of their causes.

What can a Hayekian perspective offer the committed social justice reformer? Rather than an explicit manifesto, we can derive some broad heuristics that policymakers or activists could adopt when trying to achieve their stated moral objectives, some of which I suggest here.

\section{Preservation}

One heuristic is placing substantial weight on the preservation of the market economy. Given appreciation of the resourcefulness of liberal commercial societies, we can be confident that losing market institutions or undermining them would be harmful to the interests of the disadvantaged. Many of Hayek's political views translate into injunctions against kinds of action in public policy, rather than positive proposals. He does not know, and indeed no one can know with certainty, what positive solutions to poor social outcomes will work in each case. But Hayek can say with greater confidence what interventions will impede or undermine the workings of the market economy. The Hayekian theorist puts impediment to markets on the cost side of the ledger when considering new policy and takes care that markets will still be permitted to function despite the intervention. This is not to suggest that Hayek is against any and all deliberate policy interventions. But because of the uncertainty associated with the outcomes of any intervention, reformers should aim to introduce those that are responsive to negative feedback and can be reformed or rolled back should they fail.

This is one reason why contemporary theorists drawing on the Hayekian tradition prefer federal institutions and devolution of power over national policy. The problem from the perspective of a static conception of social justice is that any variation in policy inducing different distributive outcomes within a national community appears to be a source of arbitrary inequality (it allows 
some people living within some sub-national political units to do better than others) (Bennett, 2016). From a dynamic perspective, these inequalities are acceptable if they result from legitimate rule-bound institutions that respect personal liberties (allowing freedom of exit from one district to another) and contribute to social knowledge that allows better policies to emerge and spread. Indeed, it is theorized (in conjunction with historical evidence) that federal institutions are those most likely to encourage the preservation of market institutions themselves (Hayek, 1939; North et al., 2009; Weingast, 1995).

The resourcefulness of market institutions is currently widely acknowledged across the political spectrum. Few theorists or activists propose upending them. However, an exception is sometimes found when it comes to environmental problems and especially the problem of climate justice in the wake of anthropogenic climate change. A common argument is that capitalism is intrinsically incompatible with maintaining an environment suitable for continued human life on Earth (Geuss, 2008: xii-xiii). Here the comparative institutional analysis underpinning appreciative theory comes to the fore. While climate change (a paradigmatic global externality) presents a great difficulty for market institutions, neither history nor contemporary evidence suggests that non-market economies are capable of overcoming them (Shahar, 2015, 2017). Given the other benefits of markets as they stand for human wellbeing, disposing of them now based on a purely theoretical connection between market activity (as opposed to productive human activity in general) and climate change is unwarranted.

\section{Diagnosis}

A second heuristic is diagnostic. Given appreciation of the remarkable resilience of market processes to deal with epistemic and incentive barriers to beneficial co-operation, policymakers should look on a poor social outcome with a strong theoretical prior that something is preventing people from finding voluntary means to improve it. For example, it might be that a minority or disadvantaged group lack formal or effective access to standard legal protections and remedies, a failure of equality before the law. It could be that law enforcement is discriminatory or predatory towards the group constituting a failure of the rule of law. It might turn out that responsibility for a bad outcome lies in a regulatory intervention that (intentionally or not) ends up imposing prohibitive costs on those who might supply a solution. 
A contemporary illustration can be found in the problem that rental and purchase costs for homes in areas of high employment have risen above what workers can reasonably afford. A common way of looking at this problem is that it is an example of market failure caused by the quasimonopolistic nature of land ownership and a speculative financial system. But if the underlying reason for expensive housing is that the ordinary workings of the market have been stymied in that sector then regulatory interventions could introduce more costs without solving the underlying problem, and in some cases exacerbating it (Diamond et al., 2019). There is empirical evidence that land-use planning regulation or restrictive zoning, often popular with existing homeowners, is the most important explanation for the rise in housing costs (Cheshire and Sheppard, 1989; Glaeser and Gyourko, 2018; Rognlie, 2016). An appreciative perspective suggests giving that explanation a stronger weight than alternatives because it coheres with a broader understanding of the typical epistemic properties of the market process.

\section{Public choice and democracy}

A third heuristic is an alertness to the dynamics of interventionism, or unintended consequences emerging within political processes (Boettke and Leeson, 2002). The key premise is that just as spontaneous orders emerge within market settings, so too does competition in the political sphere produce outcomes that are the result of human action but not of any single intention (Hebert, 2018; Wagner, 2016). What makes the beneficial outcomes produced through market processes ordinarily resilient is that market institutions are both incentive-compatible and have compelling epistemic properties. People participate in them because they receive positive feedback in terms of income and profit when they produce marketable value. The reason why markets generally display these responsive features is that they are based on exchange and contract within a framework of secure property rights. Voluntary consent against a background of established rights has a strong tendency to lead to incremental improvements in modes of cooperation.

In contrast, the political process, by design, allows controlling majorities, or organized minorities, to determine a direction of policy (Congleton, 2003; Tullock, 1959). This allows political processes to overcome some collective actions problems when it comes to the provision of public goods and the addressing externalities. Nevertheless, it means there are always opportunities to force people to accept conditions that are worse than their status quo as part of the decision-making process. This can spontaneously produce socially unjust outcomes just as 
surely as the unintended consequences of some market activities. Moreover, the continuous use of such processes can normalize the use of coercion as a means for powerful groups to achieve their ends (Boettke and Thompson, 2019; Meadowcroft, 2014).

The implication of recognizing the internal dynamics of politics is that state institutions are not a neutral toolkit that can be directed to any given ends, including a model of social justice. Instead, there are internal logics to state action that can spontaneously direct policymakers to coercive, or otherwise damaging, solutions to social problems even when that is not any individual's intent. There are some well-established mechanisms within democracies that help constrain the authoritarian tendencies of state action (Boettke et al., 2016), including competitive elections, federal institutions and constitutional constraints that ensure due process and that laws applicable to all. The pursuit of social justice must be compatible with this liberal institutional framework lest the political process ceases to be responsive to the needs of those participating in it.

\section{Conclusion}

Boettke (2018) shows that economists adopting a neoclassical perspective can easily misunderstand a key theme of Hayek's work: an informal appreciation of market institutions as capable of ameliorating pervasive ignorance and error in people's attempts to cooperate at the scale of a political community. I have argued that this lack of an appreciative lens also limits the engagement of some social justice theorists with Hayek's insight. Once established, an appreciative theory can furnish a useful set of heuristics for engaging in productive reform of social injustice within society.

\section{References}

Acemoglu D and Robinson J (2015) The Rise and Decline of General Laws of Capitalism. Journal of Economic Perspectives 29(1): 3-28.

Albrecht BC (2017) The Breakdown of Spontaneous Order: Smith and Hayek Diverge. New York University Journal of Law and Liberty 11: 346-370.

Albrecht BC and Kogelmann B (2018) Coase, the Austrians, and Models as Foils. Draft paper. Available at: https://briancalbrecht.github.io/models-as-foils.pdf.

Bennett M (2016) Experiments in Distributive Justice and Their Limits. Critical Review 28(3-4): 461-483. DOI: 10.1080/08913811.2016.1254318. 
Boettke PJ (1997) Where did economics go wrong? Modern economics as flight from reality. Critical Review 11(1): 11-64.

Boettke PJ (2002) Information and knowledge: Austrian economics in search of its uniqueness. The Review of Austrian Economics 15(4): 263-274.

Boettke PJ (2018) F. A. Hayek: Economics, Political Economy and Social Philosophy. Great thinkers in economics. London: Palgrave Macmillan.

Boettke PJ and Candela RA (2017) The Intellectual Context of FA Hayek's The Road to Serfdom. The Journal of Private Enterprise 32(1): 29-44.

Boettke PJ and Coyne CJ (2009) Context Matters: Institutions and Entrepreneurship. Foundations and trends in entrepreneurship. Boston: Now.

Boettke PJ and Leeson PT (2002) Hayek, Arrow, and the Problems of Democratic Decision-Making. Journal of Public Finance and Public Choice 20(1): 10-20.

Boettke PJ and O'Donnell KW (2013) The Failed Appropriation of F. A. Hayek by Formalist Economics. Critical Review 25(3-4): 305-341. DOI: 10.1080/08913811.2013.853857.

Boettke PJ and Storr VH (2002) Post-classical political economy: Polity, society and economy in Weber, Mises and Hayek. American Journal of Economics and Sociology: 161-191.

Boettke PJ and Thompson HA (2019) Identity and off-diagonals: how permanent winning coalitions destroy democratic governance. Public Choice. DOI: 10.1007/s11127-019-00683-7.

Boettke PJ, Coyne CJ and Leeson PT (2005) The continuing relevance of F.A. Hayek's political economy. In: Kurrild-Klitgaard P (ed.) Explorations in Austrian Economics. Advances in Austrian Economics. London; Amsterdam: Elsevier.

Boettke PJ, Coyne CJ and Leeson PT (2013) Comparative historical political economy. Journal of Institutional Economics 9(03): 285-301. DOI: 10.1017/S1744137413000088.

Boettke PJ, Tarko V and Aligica P (2016) Why Hayek Matters: The Epistemic Dimension of Comparative Institutional Analysis. In: Boettke PJ and Storr VH (eds) Advances in Austrian Economics. Emerald Group Publishing Limited, pp. 163-185. DOI: 10.1108/S1529-213420160000021006.

Caldwell B (2004) Some Reflections on F.A. Hayek's The Sensory Order. Journal of Bioeconomics 6(3): 239-254. DOI: 10.1007/s10818-004-5505-9.

Carens JH (1981) Equality, Moral Incentives, and the Market: An Essay in Utopian Politico-Economic Theory. Chicago: University of Chicago Press.

Cheshire P and Sheppard S (1989) British Planning Policy and Access to Housing: Some Empirical Estimates. Urban Studies 26(5): 469-485. DOI: 10.1080/00420988920080541.

Cohen GA (2003) Facts and Principles. Philosophy \& Public Affairs 31(3): 211-245. DOI: 10.1111/j.10884963.2003.00211.x. 
Congleton RD (2003) Generality and the Efficiency of Government Decision Making. In: Rowley CK and Schneider F (eds) The Encyclopedia of Public Choice. Boston, MA: Springer US, pp. 585-588. DOI: 10.1007/978-0-306-47828-4_109.

Cowen N (Forthcoming) Hayek: Postatomic Liberal. In: Callahan G and McIntyre K (eds) Critics of Enlightenment Rationalism. Palgrave Studies in Classical Liberalism. London: Palgrave Macmillan.

Cowen N (2017) Why be robust? The contribution of market process theory to the Robust Political Economy research program. In: Boettke PJ, Coyne CJ, and Storr V (eds) Interdisciplinary Studies of the Market Order: New Applications of Market Process Theory. London: Rowman and Littlefield International Ltd, pp. 63-85.

Cowen N (2018) Mill's radical end of laissez-faire: A review essay of the political economy of progress: John Stuart Mill and modern radicalism. The Review of Austrian Economics 31(3): 373-386. DOI: 10.1007/s11138-017-0387-y.

D'Amico D (2015) Spontaneous Order. In: Coyne CJ and Boettke PJ (eds) The Oxford Handbook of Austrian Economics. Oxford University Press. Available at: http://www.oxfordhandbooks.com/view/10.1093/oxfordhb/9780199811762.001.0001/oxfordh b-9780199811762-e-6 (accessed 22 March 2016).

Delmotte C and Cowen N (2019) The mirage of mark-to-market: distributive justice and alternatives to capital taxation. Critical Review of International Social and Political Philosophy: 1-24. DOI: 10.1080/13698230.2019.1644585.

Diamond R, McQuade T and Qian F (2019) The Effects of Rent Control Expansion on Tenants, Landlords, and Inequality: Evidence from San Francisco. American Economic Review 109(9): 3365-3394. DOI: 10.1257/aer.20181289.

Furton G and Martin AG (2018) What Can Economists Do? Appreciative Theory, Market Design, and Open Systems. Working Paper. Texas Tech University. Available at: https://papers.ssrn.com/sol3/papers.cfm?abstract_id=3276897.

Gamble A (2013) Hayek and Liberty. Critical Review 25(3-4): 342-363. DOI: 10.1080/08913811.2013.854044.

Geuss R (2008) Philosophy and Real Politics. Princeton: Princeton University Press.

Glaeser E and Gyourko J (2018) The Economic Implications of Housing Supply. Journal of Economic Perspectives 32(1): 3-30. DOI: 10.1257/jep.32.1.3.

Griffiths S (2014) Engaging Enemies: Hayek and the Left. London: Rowman \& Littlefield.

Hayek FA (1939) Hayek, Friedrich A. "The economic conditions of interstate federalism. New Commonwealth Quarterly 5(2): 131-149.

Hayek FA von (1937) Economics and Knowledge. Economica 4(13): 33-54. DOI: 10.2307/2548786. 
Hayek FA von (1945) The Use of Knowledge in Society. American Economic Review 35(4): 519-530.

Hayek FA von (1952) The Sensory Order: An Inquiry into the Foundations of Theoretical Psychology. Chicago, Ill.: University of Chicago Press.

Hayek FA von (1976) Law, Legislation and Liberty: A New Statement of the Liberal Principles of Justice and Political Economy. 2, the Mirage of Social Justice. Chicago: University of Chicago Press.

Hayek FA von (1981) Kinds of Order in Society. New Individualist Review. Available at: http://files.libertyfund.org/files/2493/Hayek_KindsOrder1964.pdf (accessed 16 August 2013).

Hebert DJ (2018) Chapter 8 The Spontaneous Order of Politics. In: Horwitz S (ed.) Advances in Austrian Economics. Emerald Publishing Limited, pp. 131-144. DOI: 10.1108/S1529213420180000023010.

Höpfl HM (1978) From Savage to Scotsman: Conjectural History in the Scottish Enlightenment. Journal of British Studies 17(2): 19-40. DOI: 10.1086/385720.

Johnston D (1997) Hayek's attack on social justice. Critical Review 11(1): 81-100. DOI: 10.1080/08913819708443445.

Kiesling L (2015) The Knowledge Problem. In: Coyne CJ and Boettke PJ (eds) The Oxford Handbook of Austrian Economics. Oxford University Press. DOI: 10.1093/oxfordhb/9780199811762.013.3.

Kirzner IM (2012) Essays on Capital and Interest: An Austrian Perspective. Boettke PJ and Sautet FE (eds). The collected works of Israel M. Kirzner. Indianapolis: Liberty Fund.

Knight C (2017) Reflective Equilibrium. In: Blau A (ed.) Methods in Analytical Political Theory. Cambridge: Cambridge University Press, pp. 46-64. DOI: 10.1017/9781316162576.005.

Knight FH (1921) Risk, Uncertainty, and Profit. Boston and New York: Houghton Mifflin Company.

Kukathas C and Pettit P (1990) Rawls : A Theory of Justice and Its Critics. Cambridge: Polity.

Lavoie D (1986) The market as a procedure for discovery and conveyance of inarticulate knowledge. Comparative Economic Studies 28(1): 1-19.

Leeson PT and Boettke PJ (2009) Two-tiered entrepreneurship and economic development. International Review of Law and Economics 29(3): 252-259. DOI: 10.1016/j.irle.2009.02.005.

Lister A (2013) The "Mirage" of Social Justice: Hayek Against (and For) Rawls. Critical Review 25(3-4): 409-444.

Lister A (2017) Markets, desert, and reciprocity. Politics, Philosophy \& Economics 16(1): 47-69. DOI: $10.1177 / 1470594 \times 16684813$.

Lukes S (1997) Social justice: The Hayekian challenge. Critical Review 11(1): 65-80. DOI: $10.1080 / 08913819708443444$. 
McCloskey DN (2007) The Bourgeois Virtues: Ethics for an Age of Commerce. Chicago: University of Chicago Press ;

McDermott D (2008) Analytical Political Philosophy. In: Leopold D and Stears M (eds) Political Theory: Methods and Approaches. Oxford ; New York: Oxford University Press, pp. 11-28.

Meade JE (2012) Efficiency, Equality and the Ownership of Property. Abingdon, Oxon; New York: Routledge.

Meadowcroft J (2014) Exchange, unanimity and consent: a defence of the public choice account of power. Public Choice 158(1-2): 85-100. DOI: 10.1007/s11127-012-9925-0.

Menger C (1985) Investigations into the Method of the Social Sciences, with Special Reference to Economics. Schneider L (ed.). The Institute for Humane Studies series in economic theory. New York: New York University Press.

Miller D (1990) Market, State, and Community: Theoretical Foundations of Market Socialism. Oxford: Clarendon.

Nelson RR and Winter SG (2004) An Evolutionary Theory of Economic Change. digitally reprinted. Cambridge, Mass.: The Belknap Press of Harvard Univ. Press.

North DC, Wallis JJ and Weingast BR (2009) Violence and Social Orders: A Conceptual Framework for Interpreting Recorded Human History. Cambridge; New York: Cambridge University Press.

Novak M (2018) Inequality: An Entangled Political Economy Perspective. Palgrave studies in classical liberalism. Cham, Switzerland: Palgrave Macmillan.

Nozick R (2013) Anarchy, State, and Utopia. New York: Basic Books, a member of the Perseus Books Group.

Ostrom V (1993) Epistemic choice and public choice. Public Choice 77(1): 163-176.

Piketty T (2014) Capital in the Twenty-First Century. Cambridge Massachusetts: The Belknap Press of Harvard University Press.

Plant R (2010) The Neo-Liberal State. Oxford: Oxford Univ. Press.

Rawls J (1971) A Theory of Justice. Oxford: Oxford University Press.

Rawls J (1999) A Theory of Justice. Cambridge, Mass.: Belknap Press of Harvard University Press.

Rognlie M (2016) Deciphering the Fall and Rise in the Net Capital Share: Accumulation or Scarcity? Brookings papers on economic activity 2015(1): 1-69.

Samuelson PA (1947) Economic Foundations of Economic Analysis. Cambridge: Harvard University Press.

Schmidtz D (2010) Property and Justice. Social Philosophy and Policy 27(1): 79-100. DOI:

$10.1017 /$ S0265052509990045. 
Schmidtz D and Brennan J (2012) Classical Liberalism. In: Estlund D (ed.) The Oxford Handbook of Political Philosophy. Oxford handbooks. New York: Oxford University Press, pp. 115-132.

Shahar DC (2015) Rejecting Eco-Authoritarianism, Again. Environmental Values 24(3): 345-366. DOI: 10.3197/096327114X13947900181996.

Shahar DC (2017) Hayek's Legacy for Environmental Political Economy. In: Boettke PJ, Coyne CJ, and Storr VH (eds) Interdisciplinary Studies of the Market Order: New Applications of Market Process Theory. Economy, polity, and society. Lanham: Rowman \& Littlefield International, pp. 87-109.

Swift A (2010) Political Philosophy: A Beginners' Guide for Students and Politicians. 2.ed., rev.expanded, repr. Cambridge: Polity.

Swift A and White S (2008) Political Theory, social science, and real politics. In: Leopold D and Stears M (eds) Political Theory: Methods and Approaches. Oxford ; New York: Oxford University Press.

Tebble AJ (2009) Hayek and social justice: a critique. Critical Review of International Social and Political Philosophy 12(4): 581-604. DOI: 10.1080/13698230903471343.

Tomasi J (2012a) Free Market Fairness. Princeton: Princeton University Press.

Tomasi J (2012b) Social justice, free market style. Public Policy Research 19(1): 26-33. DOI: 10.1111/j.1744-540X.2012.00678.x.

Trantidis A and Cowen N (2019) Hayek versus Trump: The Radical Right's Road to Serfdom. Polity.

Tullock G (1959) Problems of majority voting. Journal of political economy 67(6): 571-579.

Wagner RE (2016) Politics as a Peculiar Business: Insights from a Theory of Entangled Political Economy. New thinking in political economy. Cheltenham: Edward Elgar Publishing.

Weingast BR (1995) The economic role of political institutions: Market-preserving federalism and economic development. Journal of Law, Economics, \& Organization 11(1): 1-31.

Williams J (1997) On the road again: Hayek and the rule of law. Critical Review 11(1): 101-120. DOI: $10.1080 / 08913819708443446$. 